\title{
「家」の創設々家憲一家害制定者の「家」一 \\ Ie Founder and Family Law
}

米村 千代

YONEMURA Chiyo

\begin{abstract}
Most previous studies on $i e$ have conceptualized $i e$ as the model of pre-modern feudal family under the impacts of pre-war political system. With this narrow difinition, the various meanings of $i e$ held by people in those times have been neglected. The objective of this paper is to describe the positive meaning of $i e$ in terms of $i e$ founders or successors. Using the data from family laws of merchant houses in the Edo or the Meiji era, we found that they maintained the ambitions to found or sustain their own ie throughout many generations and tried to realize their ambitions in various ways. The results of this research suggest that these positive intention must be understood as a value held among people in those times not as consequences of a feudal political system.
\end{abstract}

1.はじめに一「家」把握の位相と家憲分析一

本稿では、江戸、明治期に作成された酷家の家憲とその制定に携わった人物の分析を通 して、当時の人々が抱いていた生きた「家」像を把握することを目的とする。商家の家憲、 家訓については、すでに経営史の領域でかなりの先行研究がある。しかし、その多くは、 商家の経営との関連で問題にされている。例えば、家憲の規程、その背後にある「家」が、 実際の経営にどのように生かされていたか、その結果、経営は発展したか、しなかったか 等が論点となる。もちろん本稿です、現実の経営との関連は関心事ではある。しかし、本 稿にとって焦点となるのは、家憲の制定者か、どのような「家」を志向して家憲を制定し たかということである。ここで、「家」とは、人々が超世代的に存続を希求する一つの価 值として考える。この価値か、ここでとりあげる人々の生活や家業経営の根底にあり、個 々人一本稿では家憲制定に携わった人物一の抱いていた価値が、個々の家の運営をある程 度決定づけたと考える。また、語法として、断りなく家と言う場合、制定者か、「家」を 適用、投影しようとした現実の生活を指すこととする。

このように「家」を人々の意識レベルに定位して価値として捉える意義は以下の二点に あると考元る。まず、第一点は、「家」を価値と考えることにより、その価値と現実生活 の関連、乘離を考察できるということである。第二点は、個々人が家」に関して抱いて いた意図を見いだすことができるということである。この側面は、以下にあげる視点から は抽出できない。

まず、戦前の家を政府の政策下での前近代的な封建制の温床、抑圧の装置とし、近代的 な理念に基つく制度改革によって変革されるべきすのと捉える立場がある。例えば、玉城 肇は、戦前の家族法制度の封建的な側面から当時の家族制度の抑圧制を指摘し、こうした

東京大学大学院博士課程 
封建的な法制度は、民主的平等的な新法制度によって变革されるべきとする(玉城, 1934)。 また川島武宜は、法制度上の家と実際との我離を指摘してはいるすのの、法制度に代表さ れる政府のイデオロギーによって次第に統合されていったと見る(川島, 1957)。これらの立 場は、確かに、戦前の家制度の持っていた狮圧制に関しては敏感であった。しかしそれ故 に、当時代を生きた人々にとって「家」像のむっていた積極的意味は看過されることとな った。この視角では、制度改革によってしか「家」の変遷を説明できず、人々は、受け身 の存在としてしか概念化されない。「家」は政策上のモデルによって単一的、静態的にの み把握される。

次に、「家」を、法制度によって代表させるのでなく、人々の生活や経営状態に即して 把握した場合です、「家の存続規範」自体を封建的な価值とする立場がある(瀨岡,1979)。 この場合、「家」の存続に関して人タが持っていた積極性は「封建的」という表現のもと に還元されてしまう。ある価值が封建的か否かを判断する基準は用意されておらず、何故、 「家」の存続を希求することが封建的なのか説明されないのである。

さらに、「家」を連続する「法人格」と捉える立場がある。例えば、堀江保蔵は、 「「家」(house)は、家族員の単なる集合体ではなく、それ自身主体性を持ちつつ、祖先か ら子孫へつながる実体であった」(堀江, 1984,5)とし、「家」自体の持つ積極的側面を指摘 する。この立場からは、「家」の連続していく過程を見いだすことは可能である。しかし、 ここでは、家長といった「家」の継承者でさえす、その「個人格」は「家の中に没入して いた」(ibid,6)とされ、個々人は、「家」という絶対的な制度の下で、「家というバトン を祖先から子孫へ引き継ぐリレーの選手」(ibid,4)として把握される。「家」は、個々人 を超えて存在する制度であり、個々人にとって所与であり、絶対的であると考元られてい る。この視角からは、「家」の担い手か、「家」を更新、再構築していく側面は把握でき ない。

本稿では、これらの視角に対し、生きた「家」像は多様性と可変性を持っており、それ は、「家」の継承の担い手が、それぞれの「家」像を模索し、現実㒀用しようとした結 果であると考え、この点を家憲の分析を通して明らかにする。家憲にみられる諸規則は、 作成者の抱いていた「家」像および目指そうとする「家」を表していると考元られ、その 改訂は、その背後にある「家」の改訂を意味するのである。家憲は、家がぞのような状況 下におかれたときに作成され、また改訂されたのか。そしてその際、どのような「家」が 目指されたのか。この分析からは、政策上の「家」モ宁ルを軗衍して実際の「家」を語る 梘角や、緇対的な制度として「家」を捉える視角からは知ることのできない生きた「家」 理念を知ることが可能になる。「家」か、その継承の担い手により、積極的に再構成され 継承されていった側面を把握することが本稿の課題である。

また、語法として、家憲、家法、家訓、店訓、店法等を家憲と総称するが、明治期以降 の個々の家の家憲は、特に「家憲」と表現する。

\section{2 . 商家の家憲と創業者一家業成立期の家憲制定者とその背景一}

商家にとっての「家」の特徵は、農家では、「家」の存続にとって家産としての土地が 重要であったのに対し、家業の存続、それに必要な資産が最重要視されていた点である。 商家では、家法の作成む家業の経営状態と密接に関連しており、「家」は、空間の隔たり や血縁関係を超えて思念され得るすのであった。商いが、「家」の業であり、その発展が 
「家」の発展、存続と重なって思念されていたということは、「家」が単に家族原理にお いてのみ解釈され得るべきでむなく、同様に経営原理においてのみ解釈され得るすのです ない拡がり、柔軟性を持っていたことを意味する。商家の家法は、この「家」という価値 が持ち得た拡がりを際だたせる格好の資料である。なお、本稿では、紙幅の都合上、対象 を近世における家業成立期から明治維新後に限定する。

以下、まず、家憲作成者がどのような意図で、制定に至ったのか「家」の創設が近世に 遡る家々について考察を加える。早い時期に作成された家憲からは、ある個人によって創 始された事業が「家」業とされ、「家」が形成されていった過程、各「家」の原型を見い だすことができると考える。さらに、明治維新後の変容、及び、維新後の新興の家の家憲 を順を追って考察していきたい。

三井家では、成文法としては、享保7年(1722)、当時の家長高平が「宗竺遭書」を作成 している。制定当時の三井家は、宝永 7年(1710)「大元方」の設置を経て、高平の父高利 が拡大、発展させた経営を、三井家のもとに統合していく試行錯誤の過程にあった。大元 方では、各店の人事の決定、各家の支払い（社寺への支払い、結婚費用等）の支出などを 行った(三井文軍, 1980a , 93-)。大元方設置の背景には、宝永年間に入って、高平ら兄弟が、 営業の第一線を離れて江戸から京都へ移住するようになり、江戸の営業を取り仕切るため の経営組織を整える必要が出てきたことがある。兄弟で直接朵配をふるっていた経営を他 者に委ねる状況が生じてきたのである。大元方の運営が試行錯誤を繰り返していく中で、 高平は、敦保七年(1722）「宗竺遺書」を制定する。冒頭に、「一我家者宗寿より伝へ置れ 候家業致相続、于今至益繁昌する事、是祖父之冥加也、子孫弥難有可存事」と先祖伝来の 家業を重視することとし、さらに、「一同苗共益を同ふし、上に立つむの八下をめぐみ、 下たる者は上をうやまふへし、我々八兄弟にしてむつましく、此末は又左にあらす、然は 弥心ひとつにし、建固家法・礼義をみたさす」と兄弟で相和していくことを説く(三井文庫, 1973,1）。「遺書」にある兄弟一致の原則、本家、連家の序列化は、明治期以降む貫かれる 三井家の基本理念となる。ここで、大元方は本家六軒、連家三軒で構成するとし、三井家 を統括する親分について、宗竺、宗印（高治）、宗利（高伴）の順でその地位につくよう 指定した。また、身上割や元メ等の設置については、父高利の「宗寿遺書」と比べて、家 間の配分を增やし、元メなど「後見の家」は本家、連家などから除外し、手代の一員とし て位置づける(1)。兄弟を中核とし後見の家を周辺化する、三井「家」の原型の形成である。

高利、高平の代において、三井家の事業は、地理的空間を超え、血縁関係を超えて拡大 していった。この時点で、高平にとっての「家」は、兄弟や親戚を中核とした、事業全体 であった。同族組織全体を統合し、存続していくことが「家」の存続にとって重要であっ た。つまり単なる血筋の存続ではなく、血統を中核に持つ事業全体を「家」として統合し ようという意識は、この時既に形成されていた。

「家」の存続が事業（「家」業）の存続として思念されていたという点では、山中宗利 （三代津池善右衛門）屯同様である。しかし、宗利の「家」は高平のそれと比して、より 本家中心的であった。鸿池は、三代宗利時代に一応の安定を見たといわれているが、その 宗利は正徳6年(1716)に「先祖之規範併家務」を定めている。この家法では、相続に際し ては約九分を嫡子に譲ること、本業以外の商売の禁止などを定めている(2)。他の事業にう かつに手を染めてはいけないという規定は他家にも見られるが、宗利の場合、特に強かっ たといえる。この新儀停止の観念は、鸿池の家業の運営に効力を持ち続けるのである。実 際、享保以降代々鸿池は、分別家を制限し、貸付業を家業として特化させ、規模の拡大を 
決して望まなかった。宗利の「家」は、三井高平と比して、より固定的であり、いわば創 業者の「家」そのままに次世代へと継承されていくのである。

三井、淮池と同様、住友においても、家政改革の必要性から家憲を制定している。住友 家では、住友家初代政友(1585-1652)晩年の「文殊院旨意書」を始めとして、数多くの家法 が制定されている。現在判明しているむのは、友昌の代(第五代)に集中している(3)。友昌 は、元来病弱であり、家政を実際取り仕切ったのは、弟友俊であったと伝えられている(皇 山1988,50）。友俊は、家政改革を委礼られたとき、すでに分家して入江姓を名乗っていた。 住友本家の家督を継ぐことはなかったにも関わらず、本家を自身の「家」として認識し、 その存続を希求していたのである。ここで分別家が本家を補佐し、共に経営を担っていく 住友の「家」の原型が形成されたのである。友俊の作成したすのには、店則、店訓として、 別家や奉公人に精神的訓戒を説くという性質のものが多い(作道, 1979,98-)。この背景には、 別家、奉公人が共に「家」を担っていくという意識がある。友俊にとっての緊要な課題は、 別家、使用人の統率であったのであり、それが可能になってこそ「家」でありえたのであ る。家憲を「家」規範の成文化とみるならば、その規範制定の担い手が、家長ではなく、 その弟であり、番頭であったことは三井との比較において興味深い。「家」を存続させよ うという意識が、「家」の継承者であった家長以外の人間にとっても共有されており、そ のことが、住友「家」の存続にとって重要な意味を持っていたのである。

上の三家だけでむ、家憲は、それぞれ独自の性格を持っており、制定者の積極的な意図 を反映したすのであり、その自負や危惧の表現であることがわかる。創設者の意図とは、 自らが創設むしくは発展させた「家」を確実に存続させていこうという思いである。特に、 分別家の処遇や、番頭の権限は各人の抱く「家」の差異を際立たせている(4)。

これらの差異は、家憲制定者が継承してきた「家」像の差異と、その「家」の存続の可 能性の考虑の結果、生じた差異である。それそれれ家の実践論理に即した存続方法が取ら れており、そこで目指されているのは、家族の結合を強化することだけです、事業を拡大 していくことだけでもない。それそれの「家」を存続していくことである。存続方法の差 異は、「家」を存続させようという意四が独立変数となって、個々の制定者が抱いていた

「家」像と現実の家業の経営状態との照合から生じたと考えられる。

近世においてある程度安定した基盤を形成した家々では、その功労者は筑き上げた「家」 を確実に次世代へ伝えようという意図を強く抱いていた。有賀が指摘するように、家憲は、 「家の永い存続をねがう痛切な心情」の「結晶であり、それによって彼らの痛切なねがい を保証しようとする役割を持つ」(有賀, 1955 $\rightarrow 1969,244$ )のである。「家」であると認識さ れた具体的な経営体やその存続のさせ方には相違があるが、事業の発展が「家」の発展と 同義に考えられており、その存続を希求するという意図が前提となって、始めて事業の発 展が望まれているという意味では共通であった。

以上、近世の家憲から、制定者の抱いていた「家」像の差異とその存続への意図につい て論じてきたか、、家憲の制定には、家業の運営状況や家族構成と同時に、時代状況む大き く関わっていた。以下では、明治維新後のそれについて、家憲の改訂、及び維新後の新興 の家々について考察を加え、「家」の可変性について言及していく。

3.「家」の再構成－「家憲」の制定と新興の「家」一

明治期以前から隆盛を極めていた家々の担い手にとって、維新はどのようなインパクト 
を持ったのか。本節では、明治期以降作成された家憲について、その改訂の契機を考察 する。明治期以降の家憲と、明治期以前のそれを大きく分ける指標の一つは、家「憲」と いう名称の出現である。これは、新しく彼らの前に出現した国家規範との関俰を象徵して いる。近世における家憲の条項の最初には「御公儀」に対する項目が揭げられていること が多く、幕府との関保は「家」の存続に関わる関心事ではあった ${ }^{(5)}$ 。しかし、民法や商法 という形で、家内部の規範まで規定されるようになるのは明治期以降のことである。近世 から家憲を持つ家々か、、家法、家侰といったこれまでの呼称を改め、「家憲」として改訂 したところに、国家法に対する意識を読みとることができる。明治期の国家法と家憲との 距離についてはすでに別稿で論じたため、ここでは絽り返さないが(日)、国家法とどう距離 をとるかということは継承者にとって大きな問題であった。国家による規籍の提示を始め とする、維新後の時勢の変化に対して、継承者たちは、どのように自身の「家」像を修正 し、再構成しようとしたのだろうか。この点に関して、以下では井における「家憲」制 定までの過程を中心に分析し、「家」の継承と再編成について考察を加える。

\section{（1）三井における「家」の担い手と家憲}

近世三井において、「宗竺遭書」やその基本理念を抜粋した「家法式目」は、会合の際 詠み上げられるなど、日常、人々を戒めるのに用いられていた(三井文庫, 1980a, 131-132)。 「宗䇥遺書」には、「家」を興した始祖の言としての象徵的意味が付与されていた。実際 「宗竺遺書」は「三井家憲」の制定まで家憲として維持される。三井家憲は、明治2 4 年 に「三井家憲第一草案」及び「三井家憲第二草案」を経て、三井十一家の家長の連名によ って、明治3 3年(1900)に施行された。

「三井家憲第一草案」及び「三井家憲第二草案」は、その作成を穂積陳重に委啒してい る。家憲制定の動きの一端には、新時代に即した家憲の制定という事情に加えて、幕末・ 維新期を乗り切るために新政府とのいわば交渉役として迎えられた三野村利左衛門に対す る同族の反発むあった。三野村は、家政改革の一貫として大元方の権限を縮小し、「三井 組の家産は三井組の有にして三井氏の有に非す」、「三井組は一家の主人より重く、一人 の不良は同氏一姓の盛衰、手代一同の存亡に関するを以てなり」（大元方規則章程、明治 7 年)（三野村, 1969,114-115）と揭け、経営体全体の発展、存続を最優先する施策をとった。 その意図するところは、三井の事業（ここでは「三井銀行」）に同族の権限をできるだけ 及ぼさないようにすることでああった。しかし同族内部では、三野村亡き後、再び同族の 権力を拡大、確立することから三井を改革しようという動きがあった。三野村を始めとし たいわゆる番頭の存在は、「家」の発展の上で必要不可欠であったと同時に、同族の権威 を侵犯する存在であったことも確かであった。このように、血縁関俰に基づく同族組織を 強化しながらむ、番頭として有能な人材を登用するという方法は、三井独特の戦略であり、 高福むその戦略から三野村を登用し、改革を計ったのである(7)。高福は、激動の維新期を 乗り切るために三野村を登用したが、彼がとった施策は、まさに新しい「家」像の模索で あった。そこには、先祖伝来の「家」を守りつつ、時勢に応して経営を変革していこうと いう葛藤が見られる。この葛藤は、三野村死後、明治17年、宗竺遺書の理念を復活し、三 井組を「家」業として再編しようという家政改革意見として明らかになる。番頭制に対す る三井一族の不満は、高福以降の世代へも受け継がれ、これが、ひいては草案作成、家憲 制定へと連なっていくことになるのである。

二つの草案は、まず箖積陳重によって「第一草案」が提出され、それが同族内で検討さ 
れ、穂積によって修正されたのが「第二草案」である。徉って、第一草案と第二草案とを 比較してみると、三井一族の意向を鑑みることができる。第一草案と第二草案との大きな 相違は、同族を十一家に固定しているという点と、財産規定がより細かくなっているとい う点である。また同族会議に関しては、第二草案では、その統制に服することが義務づけ られ、反する場合の制裁規定が設けられている。同族間の争いに関しては、いかなる争い であってもこれを裁判所に提訴することを禁じている。彼らにとって三井事業全体は、同 族という核があって始めて三井「家」で有り得、またそうあるためには、同族が一致して その発展に寄与しなければならなかった。

この二つの草案を経て明治 33 年、「三井家憲」が制定された。「家憲」の冒頭に、 「・・・我同族ノ久しきを経テ愈興盛シ以テ能ク今日アルヨ致シタル所以ノモノ八、全 ク祖先/余沢二依り、居士ノ遺筬 其至恩子孫タル者之ヨ忘却シテ可ナラムヤ」とあり「遺訓」に基づいた同族の発展が唱わ れ、同時に「而シテ今や世運一変シ、遺筬古例ノミョ以テ規矩スヘカラサルモノアリ、且 此恵福 7 後裔ニ貽サム爲メ新ニ条規 $ᄏ$ 設クル!必要 7 琶メ、遺筬/趣旨及七古例/精神二 基キ、時勢二鑑ミ玄二同族ノ一致協定二頼り此家憲习制定ス」（三井文庫, 1974,344）として 時代に即した新しい規定を必要としていたことがわかる(下線引用者)。「草案」と比較し てみると、新たに制裁に一章をさいているほか、重役会という章が加えられている。第一 章では、同族を三井十一家の戸主及び、家督相続人とする。うち、六家を本家、うち三井 八郎右衛門の一家を「宗竺居士の遺訓二基キ」、総領家とし、五家を連家とする。第二章 「同族ノ義務」は、「第一草案」にはなく、「第二草案」で新たに加えられた章であるが 兄弟で家業をむり立てていくことを説き ${ }^{(8)} 、 三$ 井の家風を守ることを義務づけ、さらに第 十四条では、同族間の争いを裁判所に提訴することを禁止する。同族の問題はあくまで同 族内の規則で対処していこうという強固な姿勢である。こういう規定を設けなければ、同 族が分散していく危惧も抱かれていたのである。特に新政府下では、法的に各家の分離独 立は可能であった。各「家」間の相克が内在していたことをこの章は暗示している。第三 章から第六章は、同族会の権限および、決議権の規定、同族会への報告義務が記されてい る。通底しているのは、同族は、鿵居、婚姻、分家等々常に同族会に同いをたてて䖵可を うけなければならないということである。「遺書」以来の同族会によって三井を統括して いこうという姿勢はここです貫かれている。第七章は、各営業店の重役で構成される「重 役会」に関する規程であるが、第六十一条に「重役会ニ於テ決議シタル事項ニシテ同族会 ノ認可ヨ経へシ」とし、その権限む同族会の統括の下におく。しかしながら、「同族会ノ 決議ニシテ営業資産ノ処分若ク八增減又八其利殖法ニ関スル事項二付テハ、其決議 前二重役会ノ意見习徽スヘシ」とあるように、決議権はないむのの、三井の経営に際して のいわばご意見版としての機能を持たせた。三井における番頭は、同族との間に緊張関係 をはらんではいたものの、三野村以後む、家政改革にとって不可欠の存在として重要視さ れていたのである。また第八章の財産規定及び第九章の制裁規定は、「遺書」に対する

「家憲」の時代性を最むよく現しているといえる。財産については第七十一条に「同族ノ 財産八之ヨ分チテ、営業財産、共同財産、及七家産ノ三種卜ス」とあり、家産は同族の自 由になったが、それ以外は、家間で配分が決められており「家」の財産であった。共有財 産制を基盤として「家」を再編成していこうという意図である。また制裁規定としては、 慥責より除族までの項目を設定している。この二章では、三井十一家の基盤を共有財産制 のもとで、より強固なむのにしていこうという積極的な意図が窥える。最後に第十章の補 
則では、家憲の項目の改訂、この「家憲」中に明文のない場合は「遭書」その他の旧例に よるべきこと、家督相続人は相続開始の際に、家憲を遵守する誓約書に署名捺印すること を定めている。

「遭書」から約2 00 年を経て制定された「家憲」は、先祖の遺訓を継承し伝えていく と同時に、新政治体制下ての新しい対応が制定の目的となっていた。「遺書」と「家憲」 の共通点としては、兄弟一致の原則、同族の和合、家業の重要視、嫡系優先をあげること が出来る。相違点としては、財産規定の明確化、同族団の固定、制裁規定の明文化といっ た点があげられ、財産の拡散の防止と新法制下での「家」の維持が、㗨要の課題であった。 つまり、「家」の継承という基本理念は貫きながらむ、時代に即した存続方法が取られて いるのである。例えば財産所有について見ると、共有財産制という基本原則は一貫してい るが、「家憲」では、商法、民法の施行に対応（対抗）して、家産が個々人に拡散してい くことのないよう特に配慮する必要があった。制裁規定に一章をさいているのむ、法的に は何等根拠のない家憲を国家法に優先させるための手段であった。同様の意図で、私法で はありながらむ法としての体裁を整備する必要があったのである。また、確かに番頭の権 限は大きかったが、中枢にいたのは同族であり、同族の協同体制によって「家」は担われ ていくべきという意識があった。例えば、家憲の制定にも携わるなど三井の番頭として要 職にあった中上川彦次郎に対して、「三井高保君は常に中上川君を客分扱ひにして居たも のと見えて對談の際には、必ず自分で座蒲團を與えた」(實業之世界社, 1913,280)というエ ピソードがあり、番頭は、「家」の成員としての序列化には組み込んでいなかったことが 䇲える。「家憲」制定の目的は、経営の拡大をはかりながらも、財産が拡散していくこと のないよう細かな規定を設け、同族団によって三井の事業の全体を統括していくことであ った。しかし、あくまで同族が中心にあることが重要であった。こうした内的事情に、維 新後の社会変化という外的事情が絡んでいた。明治期の社会変化の下で、三井家として

「家」の存続を可能にするためには、政府の主導者との関係を密にし法制度の変化には敏 感に対応していく必要があった。明治期における、同族外からの人材の登用も、この意味 が大きかった。

（2）その他の家における家憲の改訂

明治以前から続く家々に、それぞれ異なった「家」の原型が形成されていたことは先に 述べた。では、三井以外では、明治期以後どのような変遷が見られるだろうか。

住友では、明治 15 年(1882)、当時の総支配人、広瀬莘平の起草による住友家法が制定 され、2 4年に改正されている。広瀬は、九歳の時、別子銅山勘定場に奉公し、三十九歳 にして総支配人の地位を得た。維新の変革で、住友家業とされた別子銅山の官収の危機、 及び資金難を乗り切った功労者である。広瀬が登場した背景には、幕末維新期における危 機的状況及びその後の体制の立て直しの必要性という住友の事情があった。

広瀬は序文に、「・・宰平讙テ按スルニ我住友家業 卜消長シ世ノ浮沈スルノ感ナキ能ハズト雖モ家ヨ伝フル今ニ・・」(宮本, 1979, 174) と揭げ、 「我住友家業」とあるように、住友を自身の「家」と思念する意識が読み取れる。丁稚を 「家」の成員と見なし、能力に庍じて昇格させるという住友の「家」を自ら経験した一人 といえる。また、その過程を経て、広瀬が「我住友家」と思念するに至ったと考えられる。 広瀬の経歴それ自身が、住友の「家」の性格を表現している。

さて、住友家法は、第十八款からなり、そのうち第一款が7条からなる「家憲」、第十 
七款が末家の規程、その他は、事業経営に関する項目となっている。第一款「家憲」では、 目頭に「我住友家長タル者八䛚テ左ノ條件 7 履行シ家業/隆盛 あるように、家長のあるべき姿を規定している。「家法」はすちろん、家長の裁定を経て 制定、施行されたものであるが、総支配人、いわば番頭が、家長に訓戒を説くという形に なっている。広瀬は、「家法」制定において従来の住友「家」を伝承しつつ改新を計った という意味で、「家」の重要な担い手であり、「家」の存続に携わる継承者であった。

広瀬が、重要な「家」の担い手であったということは、明治2 4年の家法改正を見ると より鲜明である。「新家法」では、まず、「住友家憲」と「住友家法」を分離したが、前 者においては、より総理、支配人の権限を強化させたすのになっている(9)。ここからは、 広瀬が、いかに住友で権限を持っていたかが絑える。しかしながら、広瀬は、住友内外か ら独裁的、「公私混淆」との批判を浴び(西川, 1933,130-137)、明治2 7 年には住友を退職 することとなる。このことは、住友の経営方針の不確定性を表していると同時に、番頭と

して「家」の存続を希求するという広瀬自身の不安定性むよく表している。

鸿池では、明治期に入って、22年に十二代善右衛門の時に、「鴻池家憲法」が、さら に 32 年新憲法が出されている。先に制定された鴻池家憲法の第一条には「家主八必ズ嫡 宗ヨ立ベシ」とあり、本家を重視する鸿池の「家」は健在である。善右衛門幸方が、日本 生命保険会社社長就任を依頼された際、三代宗利以来の家法に抵触するということでとの 実現が容易ではなかったとのエピソードああり(安岡, 1970,187)、「旧慣墨守」、「新儀停 止」の姿勢は一貫していた。財産管理については、第十二条に「家産八一切之ヨ老分二管 理セシメ、家主自ラ之ヨ左右スル 得ズ」とあるように、老分に一任しており、事業の拡 大に関しては消極的であった。経営史では、鴻池は財閂化せず、経営も発展しなかったと いう位置づけがされるが、本稿の文脈では、明治期以降の鸿池の展開は、「家」の存続を 第一義と考えた結果として解釈することができる。あくまで「家」の発展あっての事業の 拡大であり、当主にとっての「家」は、近世以来の鴻池「家」であり続けたのである。

上にあげた「家」の差異、多様性は、新時代下での経営の変革を、いかに彼等の「家」 に組み込むかという葛藤の表れであったといえる。これは、継承されてきた伝来の「家」 像の違いと同時に、時勢の変化の下での「家」の存続方法の違いである。また、各々の

「家」の継承が誰によって担われたかによる遣いであある。分別家の処遇は、各家の「家」 像の独自性、多様性を顕著に表現しているが、同時にそれは、分別家をどう事業に組み込 むかが、「家」の存続にとって緊要の課題であったということであある。具体的な方法と しては、上に挙げた家の他で、別家は必ず本家から食子をとらせ、男子は別家させる（伊 藤家）、別家が本家と同業は禁止（下村家）など同族結合を重視しながらす本家中心性の 強い家や(注 4 参照)、昭和期まで奉公人制度（「登制度」）を続けることから経営全体を 「家」の序列化に組み込む（西川家）などがある。制定者の「家」にどれだけ現実の経営 を統合できるか、制定者の「家」をどれだけ他の人間が共有できたかが、維新後の「家」 の存続の明暗を分けたといえる。

(3)明治期以後一新興の「家」の創始者一

上にとりあげた家々は、明治期以前から存続している旧家である。明治期における社会 変化、及び民法の発布という状況下での家憲の制定には、それまでの「家」の存続と更新 という意図があった。これに対して、明治期以降台頭してきた新興の「家」の創設者は、 明治維新後の変動期の中で、「家」を興した人々である。最後に、彼らが、どのような 
「家」を志向していたのかにふれ、上にあげた「家」と比較しておきたい。

三菱の場合、岩崎弥太郎は、明治八年「三菱汽船會社規則 立社體裁」の冒頭第一條で、 「當商會八姑ク會社ノ名 $习$ 命シ會社の體习成スト雖モ其實全ク一家ノ事業ニシテ・・」（三 菱社誌, 1959,37)と、自分が眮した会社は「家」であるという点を明確に打ち出している。 また、これに先立って明治6年九十九商會という名称を三菱に改めた際、米国留学中の弟 の弥之助に送った手紙にも、「・・巨大一家を興起致候間、貴様にも早く進歩の上帰国を 祈り候也」とあり、三菱の創業を「家」を興すことと同義に考えていたことがわかる(傳記 編纂會, 1967b, 34)。

花王石䶨の業祖、初代長瀬富郎は、明治44年、「遭書」という形で自身の意向を申し伝 えているが、「時至レバ彼等ヨカニ左/会社 設ケ、永遠長瀬繁栄/基礎トセラレンコト ヨ冀フモノナリ」(服部, 1973,246)と、「家」の繁栄を願いつつ自身が興した事業を「合資 会社」として整えようという意向を家族に申し伝えている。

近世から存続する旧家の継承者が、程度の違いこそあれ、従来までの「家」を連続して いこうという守勢の姿勢があるのに対し、彼等には、これからす守り続けていかねばなら ない「旧慣」はない。新興の「家」の創設者たちは、これから自分の「家」を形成してい こうという意味で攻勢である。彼等の「家」は、維新によって創設が可能になった「家」 であり、旧家のように従来の「家」と新しい経営との矛盾、葛藤むない。また、長瀬、岩 崎とむ創始者亡き後、残された兄弟が中心となって「家」をむり立てていく。ここでは、 創設者のカリスマ性を背景として、親族を中核にすえ、「家」（=会社）を発展させてい こうという共通項がある。

創設者のカリスマ性に加えて、さらに新興の「家」の特徴をあげるとすれば、旧家の 「家」を自身の「家」像に応してアレンジしているという点である。具体的には、他家の 家憲を模做しながら、自身の「家」の独自性を盛り込んでいるのである。この点について、 筑豊炭坑の「御三家」のうち、麻生太吉、貝島太助の「家」を取り上げておこう。

麻生太吉自身が制定した家法は、住友家法との類似性が指摘されているが(畠山,1985a)、 麻生独自の項目、「第一条、家主八祖宗正系ノ血統ヨ以テ家督相続セシメ決シテ之ヨ乱ス 可ラス」を盛り込んでいる。「家」の創始者のカリスマ性を血縁の連続から反映させよう としたと考えられる。畠山は、同様にして貝島家の家憲と三井家憲の類似性を指摘してい る(畠山, 1985b)。貝島の場合の独自性は、三井の共有財産制を適用しながらも宗家（貝島 太助）の配分が40\%を占めるなど、より宗家中心的であり、幹部を親族で固め番頭制をとら ない。太助の独裁性に基づき親族中心に「家」を担っていこうという意識が強かった。

新興の家の創設者は、自らが「家」を興したという自負と、これから「家」を発展させ ていくという意欲を抱いていた。彼らは新時代の申し子であり、その意味で新政府への適 用は、意識としては旧家ほど困難ではなかったと考えられる。しかしながら、変動期なら ではの経営の不安定性は同じである。さらに、歴史の中で蓄積された「家」の存続方法は ない。旧家の家憲の模做は、この歴史の欠如に対する一つの対応策であった。また、本家 や親族を中心に「家」を継承させていこうという方法は、自らが興した「家」を他人に委 ねたくないという創設者の意識の表われと解釈できる。可能な限り、自分に近い人間に継 承を委ねようとしたのである。このことが可能になる背景には、創設者自身が優れた経営 者であり、後継者にむ能力を習得させる手段を持っていることが必要であった。その手段 は、例えば洋行経験や学校教育であった。ある意味で「近代的な」方法を積極的に用いな がら、「家」の存続を希求するという点が新興の「家」の特徽であった。 


\section{4 . 結び}

家法の制定には、制定に携わった人間の、自らが家」を創設または発展させたという 自負と、その衰退を憂う危機意識が内包していた。家法は制定者の気迫と不安の産物であ るといえるだろう。自らの「家」を確実に次世代へ継承させようという思いは、近世、近 代を問わず制定者に共通であるが、「家」の像やその存絸のさせ方は独自である。この独 自性は、各人が継承してきた「家」像と、彼らがおかれた時代、そして「家」の投影され た現実の絡み合いの産物ですある。そこで目指されているのは、単に事業を拡大していく ことではない。そこには、自身の「家」を存続、発展させていこうという意図が強く墈い ていたのである。三井同族の力の及ばない三井組は、彼らにとって「家」では有り得なか ったのである。鴻池が財闑化に失敗したのは、彼らが「家」を維持しようとしたからであ る。また岩崎弥太郎が一代で三菱財閂を形成し得たのは、まさに彼にとってそれが「家」 であったからであるといえるかもしれない。

それぞれの「家」を存続させていく過程には、危機むあり、それに対処するために様々 な方法が採られた。特に、明治維新は、その担い手に「家」の変更を迫る共通の外的契機 であった。国家の出現は、「家」の継承者に、新しい規範を提起し、いやがおうですその 対応を迫った。これは、単に国家により新しい「家」モデルが提示されたということに留 まらない。必ずしむ、各人の「家」になじまない規範が提起され、しかむ法的に拘束力を 持つということは、彼らにとって脅威であった。かといって政府との関係において、正面 から対立することは不可能であった。また、国家規範は、内的な分裂の契機をむ引き起こ しかねない。従来の存続方法では、「家」の維持が困難になるのである。2節(1)(2)で述 ベたような明治以前から続く旧家が、明治20年代を契機として「家憲」を整備したのはこ の対応の表れである。

ここで、制定者の「家」像は、家憲の適用を通して現実の家に投影され、また家の内部 状況、外部状況に応じて書き換えられた。「家」の多様性、可変性はこの相互の関連から 生じたが、この関連の仕方によって「家」の存続の可能、不可能が決定されたのである。 その変容過程において一貫して通底していたのは、「家」を守り、存続させていこうとい う意志である。「家」の内容は多様であり、可塑的であったが、世代を超えて連なってい こうとする感覚、また自身がその存続を途絶えさせてしまうことを避けようとする意識が 存在したという共通性は指摘できる。事業の拡大む、長子による家督の継承、番頭の権限 の強化む、この価值観を基盤にした上での「家」存続の方法の一つであったのである。家 法の制定に見られる制定者にとっての「家」は、「家」の存続を希求することが自明であ り、所与であるという意味では、制度と呼んでいいかすしれない。しかし、同時に「家」 は、それがなぜであるかは問われないにしてす、存続を可能にするべく、内外の転機にお いてその担い手が再構筑していったものである。ここには「家」を存続していこうという 積極的な志向性が観察される。本稿で、「家」を価值として捉えようという意図はここに ある。法制度における「家」を敷衍して、本稿で見てきた「家」の理念を語ることはでき ないのである。ここで捉えた側面は、「家」の近世からの連続性と、連続しつつむ変化し ていく過程であり、それが個々人によって担われてきた過程である。法制度が変われば 「家」屯変わる、「家」は封建的な制度である、あるいは絶対的なすのであるといった前 提を置く議論では、この側面は説明できない。 
本稿では、江戸時代から明治維新後までの商家における「家」の担い手と家憲における 「家」の変容過程について考察を加えた。通時的に「家」の連続と变化を考察するには、 さらに、明治以降、大正、昭和を経た「家」を取りまく状況の変迋と「家」の関連につい て探究するべきであろう。この点は今後の課題としたい。

注

(1)列えば元メに定年制を設けている。

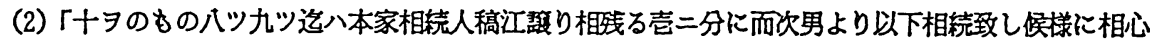

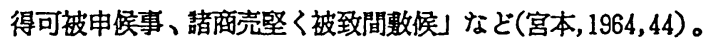

(3)(皇山, 1988,48)に「近世住友家法略年表」としてまとめられている。

(4)番頭制を早い時期からとった家としては、他に、白木屋をあげることができるだらう。白楃は、 䙾文 $10(1670)$ 年創業といわれており、業祖である初代大村彦太郎か、支配人中川胎兵衙代家法を 作らせている。また、分别家関保として特翼なるのとしては、㫗保2年(1717)創業の下村家（大丸） や、伊菲家（松坂屋）がある。下村では、「三家一致定法」を揭げ、三井家と同様、本家を中心と した血粶関保を中核としなからら、宝崕年間には20家、文化年間には60家、明治29年には63 家の別家を持った。特敀的なのは、別家か本家と同業をとることを禁止している点である。下村家 では、别家においては娘を重宝がる傾向があったといわれているか、これは、别家の存桡にとって は、有能な人材に事業を継承させることと、事業の発展に有利な姻咸関係を持つことが㗨要であり、 そういった人材を娺餈子として迎えることにより「家|の存続を確実に行おうとした別家ならでは

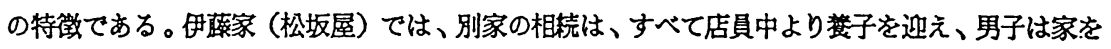
出て他家を継がせたという(岩崎, 1916,115)。さらに、別家の粉子となる店員には、主人が御曼 附」を授げ、「主人自ら父となつて緑組の式を祭ぐ」ある。本家を中心として、別家の独立性を 低く保つことから本家中心们家」を統合していこうとする存続方法である。

（5）「一 御公儀時々御法度之趣、主人者不及申手代下久迄早速申聞せ、堅相守可申候」「宗篮道書」

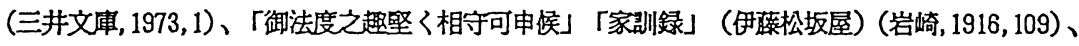
「御公俄様より仰せ出され候御法度の旨相守り申すへく候事」「白木屋䙾文家伝」(吉田, 1973, 14 8, 白木屋, 1957,79)なぞ。

(6)拙稿「「家」と家蕾一明治期における家規範と国家規範一」( 「社会科学ジャーナル」30-1 国際基 督教大学社会科学研究所)においては、当時の家規範之国家規範との美巽を中心諭した。

（7）また草案作成には井上䇾や沾沢栄一か関与している点も、当時の三井家の家政改革か外部の力によ るところか決して小さくなかったことを示している。

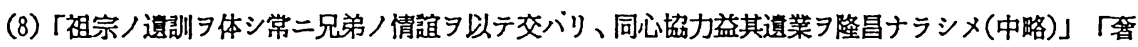
侈习禁シ節倹习守ルハ祖宗ノ定ムル所ノ三井家ノ家風ナり、同族各家八水ク此美風习保続シ、子柇 ヨシテ之ヨ確守セシムヘキ義腬アルモノトス」

（9）「第十一条一家内事二関スルモ/卜雖重大/事件八之ヨ粇理人及上支配人二誯淁/上処理スルコ

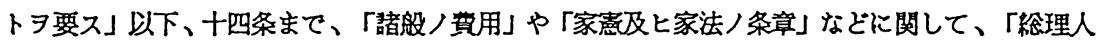
及七支配人と協議もしくは合意を得ることとする(舅山，1988,134)。

考文献

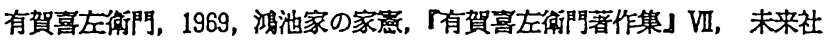
大丸二百五十年史絀集委員会，1967，「大丸二百五十年史」，大丸 搨山秀榯，1985a，筑豊麻生家の家法，「大分大学経洛論集」36-6

— ，1985b，貝島家の家罴，「大分大学経济論集」37-1

— ，1988，「住友肋閏成立史の研究」,同文館

服部之總，1973，「服部之總全集 9 初代曼瀨富郎层」，福村出版 凨江保葴，1984，「日本程営史における「家」の研究」，臨川䒼店 
岩崎徂堂, 1916(1919增補)，『富豪名門の家憲』大正書院

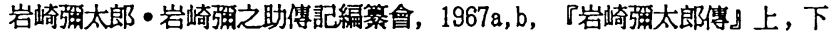

貿業之世界社, 1913，『三井之三荾』

川島武宜，1957，『イデオロギーとしての家族制度』，岩波書店

三野村清一郎, 1969, 『三野村利左衛門伝』，三友新聞社，鹿島研究所出版会

三菱社詰刊行会, 1959, 『三菱社詰』2, 東京大学出版会

三井文庫編，1973，『三井事業史 資料篇』I

$$
\text { ，1974， P三井事業史 資料篇」 III }
$$

- ，1977, 『三井事業史 資料篇』II

— ，1980a，『三井事業史」I

- ，1980b, 『三井事業史」.II

宮本又次，1958，『鸿池善右䔎門」(人物灌書)，吉川弘文館

—，1964, 鸿池善右衛門家の家訓について， 『国民経珮雑缌 110

，1974，『近世日本経営史論考」，東洋文化社

日本䅅営史研究所編, 1969, 『中上川彦次郎伝記資料』東洋経済新報社

西川400年社史編䇣委員会, 1966, 「西川400年史』

作道洋太郎, 1979, 江戸時代における住友家の家刷, 宮本又次・作道洋太郎䋧著, 『住友の経営史的研究』， 実教出版

瀬風 誠, 1979, 近代住友の経営理念, 『住友の経営史的研究d，実教出版

西川正治郎編，1933，『幽淞」，文政社

白木屋, 1957, 「白木屋三百年史」

玉城 登, 1934, 『日本家族制度批判」，福田書层

安岡重明, 1970, 『財闑形成史の研究」、ミネルヴ>書房

吉田 豊編郡, 1973, 『商家の家訓」，徳間書店 